\title{
PENGASUHAN ANAK OLEH IBU USIA REMAJA
}

\author{
PARENTING BY TEENAGE MOTHER
}

Oleh : Kristanti Sulistyo Rahayu ${ }^{1}$, Lestari Basoeki ${ }^{2}$

1 Dokter Umum, peserta PPDS I Psikiatri, Departemen/ SMF Ilmu Kedokteran Jiwa, FK Universitas Airlangga/ RSUD Dr. Soetomo, Surabaya.

Email: kristanti_sulistyo_rahayu@yahoo.com

2 Dokter Spesialis Kedokteran Jiwa/Psikiater, (Konsultan)/ Guru Besar, Staf Pengajar pada

Departemen/SMF Ilmu Kedokteran Jiwa, FK Universitas Airlangga/ RSUD Dr. Soetomo, Surabaya. 


\begin{abstract}
ABSTRAK
Pengasuhan merupakan kegiatan yang kompleks dimana terdapat penerapan pola dukungan dan kontrol. Pengasuhan ini berbeda-beda pada orangtua yang satu dengan lainnya dan akan mempengaruhi perilaku anak. Pengasuhan merupakan proses yang sulit bagi ibu usia remaja karena masih dalam usia perkembangan dan harus menuntaskan tugas-tugas masa perkembangannya, disamping berperan sebagai orangtua. Salah satu penyebab remaja berperan sebagai orangtua dikarenakan kehamilan yang tidak direncanakan. Selain itu akibat kehamilannya remaja menjadi putus sekolah, sulit mendapatkan pekerjaan yang mengakibatkan kemiskinan dan bergantung pada dukungan sosial. Dalam situasi seperti ini diperlukan dukungan dari berbagai sektor masyarakat yang mendukung ibu usia remaja mengasuh anaknya.
\end{abstract}

Kata kunci : pengasuhan, ibu, usia remaja.

\begin{abstract}
Parenting is a complex activities where there are support and control rule. There are different parenting stytle between every parent, that would affect the child's behavior. Parenting is a difficult process for teenage mothers because they are still in the developmental age that they must fullfill their own developmental task, while also playing the role as a parent. The reason why teenage girls have to become parents is because of their unplanned pregnancy. In addition, as the consequences the pregnancy, they have to quite school, become difficult to get a job, and will result in poverty and dependent on social support. This situation needs support from various sectors of the community to help them in bringing up their babies.
\end{abstract}

Keywords: parenting, mothers, teenage.

\title{
PENDAHULUAN
}

Hubungan anak dengan keluarganya merupakan hal yang penting bagi perkembangan anak. Pendekatan yang penuh kehangatan dan perhatian dari orangtua, harapan orangtua, komunikasi orangtua terhadap anak serta sikap disiplin orangtua membentuk sikap pengasuhan orangtua terhadap anak (Önder, A. \& Gülay, H., 2009). Pengasuhan merupakan kegiatan yang kompleks menurut standart orangtua, mencakup beberapa perilaku spesifik yang bertujuan untuk mempengaruhi perilaku anak (Alizadeh, S. et al., 2011).

Remaja sebagai ibu akan menghadapi tuntutan secara bersamaan, yaitu sebagai orangtua dan menyelesaikan tugas perkembangan fase remaja bagi dirinya sendiri. Sehingga diperlukan upaya untuk memahami dan memfasilitasi penyesuaian remaja dalam menghadapi perannya sebagai orangtua (Klein, H.A. \& Cordell, A.S., 1987). 


\section{PEMBAHASAN}

\section{Pola asuh}

Pola asuh merupakan pendekatan atau interaksi antara orangtua dan anak yang digunakan untuk membesarkan anak-anaknya (Joseph, M.V. \& John, J., 2008). Implikasinya adalah orangtua menyampaikan pesan sosial kepada anak-anaknya, dengan tingkat penerimaan, pemahaman dan internalisasi pesan tersebut berbeda-beda pada masing-masing anak. Pesan sosial tersebut dapat berupa pendidikan, pengalaman, sikap dan perilaku yang diperlukan supaya sukses beradaptasi dalam lingkungan masyarakat dan keluarga (Kordi, A., 2010). Terdapat dua elemen dasar dalam pola pengasuhan yaitu acceptance/ responsiveness dan demandingness/ control (Joseph, M.V. \& John, J., 2008; Merlin, C. et al., 2013).

Acceptance/ responsiveness disebut juga dukungan, penerimaan, kehangatan orangtua, dan sejauh mana keterlibatan peran orangtua terhadap kebutuhan dan tuntutan anak. Dukungan orangtua merupakan hal penting karena memberikan rasa aman, mendukung kepercayaan diri, dan kesejahteraan psikologis. Tanpa dukungan orangtua yang memadai, anak cenderung mengalami kecemasan, permusuhan, rasa tidak aman, agresif, rendah diri, dan merasa tidak mampu (Darling, N., 1999; Huver, 2010; Merlin, C. et al., 2013).

Demandingness/ control merupakan perilaku kontrol mengacu pada pernyataan orangtua yang membuat anak tetap terintegrasi pada keluarga, melalui tuntutan kedewasaan, pengawasan aktif, upaya kedisiplinan dan kesiapan orangtua untuk berdebat dengan anak yang menentang. Kontrol orangtua membantu membentuk rasa tanggungjawab dan pengendalian diri pada anak. Orangtua dalam menetapkan atau menegakkan aturan dan pedoman pada anak, akan membantu mengajarkan anak tentang standart perilaku dalam kelompok sosialnya (Darling, N., 1999; Huver, 2010).

Dengan mengacu pada dua elemen dasar ini, terdapat empat pola dasar pengasuhan yaitu permissive, authoritarian, autoritative, uninvolved (Terry, D.J., 2004; Joseph, M.V. \& John, J., 2008; Alizadeh, S. et al., 2011; Merlin, C. et al., 2013).

\subsection{Bentuk pola asuh}

Menurut Baumrind dalam tulisannya menyatakan ada empat jenis pola asuh berdasarkan sikap orangtua terhadap sikap anaknya (Baumrind, D., 1991) :

\section{Permissive/ non directive/ indulgent/ memanjakan}

Pola asuh dengan pendekatan menerima dan menyetujui perilaku dan keinginan anak tanpa mencari alasannya. Dalam hal ini orangtua memberikan kebebasan yang berlebihan pada anak dan memiliki tingkat disiplin yang rendah. Orangtua memberi dukungan yang tinggi namun daya kontrol yang rendah terhadap perilaku anaknya (Önder, A. \& Gülay, H., 2009; Alizadeh, S. et al., 2011).

\section{Authoritarian/otoriter}

Dalam pola asuh otoriter terdapat tingkat dukungan orangtua yang rendah, namun tingkat kontrol yang tinggi. Orangtua menghukum secara verbal dan nonverbal/ fisik terhadap perilaku anak 
yang tidak diharapkan. Selain itu orangtua berharap melebihi kemampuan anak, memberikan keputusan secara cepat tanpa mengevaluasi pengaruh keputusan tersebut atas anaknya. Orangtua otoriter merupakan figur yang ketat, direktif, emosional, dan mengaharapkan anak untuk tunduk terhadap tuntutan orangtua, berperilaku tepat mematuhi aturan orangtua, menerima nilai-nilai, penilaian dan tujuan orangtua tanpa mempertanyakannya (Darling, N., 1999; Joseph, M.V. \& John, J., 2008; Önder, A. \& Gülay, H., 2009; Kordi, A., 2010; Alizadeh, S. et al., 2011).

\section{Authoritative.}

Adalah pola asuh dengan pendekatan orangtua yang bersifat mendukung dan mengontrol secara berimbang. Orangtua dan anak menunjukkan kelembutan dan hubungan yang dekat baik secara verbal maupun fisik. Orangtua peduli terhadap anak dengan pendekatan yang lebih kooperatif dan harapan orangtua sesuai dengan kompetensi anak. Orangtua menghargai ide, perasaan, perilaku serta sikap yang ditunjukkan oleh anaknya. Pola asuh ini merupakan pola asuh yang ideal karena memiliki peraturan yang terbuka, jelas, dan bisa didiskusikan. Pola pengasuhan authoritative mirip dengan authoritarian dalam hal arah yang jelas dan tegas bagi anak. Namun perbedaannya terletak pada moderasi kedisiplinan dan kehangatan, alasan dan fleksibilitasnya yang terdapat dalam pengasuhan authoritative (Önder, A. \& Gülay, H., 2009; Kordi, A., 2010; Alizadeh, S. et al., 2011).

\section{Uninvolved/ neglected/ rejected}

Pengasuhan ini mempunyai nilai yang rendah dari dua elemen dasar pengasuhan baik dukungan maupun perilaku kontrol yang tercermin dalam penolakan dan pengabaian orangtua. Orangtua pada pengasuhan ini tidak membangun aturan, tidak peduli kemana arah perilaku anak. Orangtua membiarkan anaknya, tidak mengawasi, tidak mengarahkan, ataupun mendukung anaknya. Orangtua pada kelompok ini mempunyai masalah pada diri mereka sendiri dan cenderung melepaskan tanggungjawab. Pengasuhan ini dipandang sebagai pengasuhan terburuk oleh karena tidak memberikan dukungan maupun batasan (Darling, N., 1999; Terry, D.J., 2004; Merlin, C. et al., 2013).

\subsection{Pengaruh pola asuh terhadp perilaku anak}

\section{Permissive/ non directive/ indulgent/memanjakan}

Pengasuhan ini menghasilkan anak yang memiliki tingkat harga diri dan ketrampilan sosial yang tinggi, namun memiliki tingkat pengaturan diri yang rendah, sehingga rentan terhadap masalah perilaku dan umumnya sulit menerima tanggungjawab, sering impulsif dan agresif, cenderung egois, kurang kontrol diri dan rendahnya kemandirian dan prestasi, tidak peduli terhadap perasaan dan pikiran orang lain (Joseph, M.V. \& John, J., 2008; Önder, A. \& Gülay, H., 2009).

\section{Authoritarian/otoriter}

Pola asuh otoriter umumnya menyebabkan anak menjadi sangat patuh, jarang terlibat dalam masalah perilaku, dan cenderung cukup baik disekolah. Anak dengan pengasuhan otoriter kurang memiliki spontanitas, jarang mengambil inisisatif, oleh karena orangtua tidak membiarkan anaknya untuk memilih, memiliki sedikit kesempatan untuk belajar kemandirian dan cenderung kurang percaya diri dalam kemampuan pengambilan keputusan bagi dirinya sendiri. Anak dari 
cenderung mengalami kecemasan, kegelisahan, memiliki tingkat kebahagiaan dan harga diri yang rendah, lebih sering menggunakan kekerasan fisik ketika marah, serta memiliki kompetensi sosial dan kemampuan ketrampilan berkomunikasi yang rendah. Dalam pergaulan mereka kurang aktif dan memandang orang lain untuk memutuskan apa yang benar (Darling, N., 1999; Joseph, M.V. \& John, J., 2008; Önder, A. \& Gülay, H., 2009).

\section{Authoritative}

Anak yang dibesarkan oleh orangtua authoritative merupakan anakyang ceria, lebih memiliki kemampuan bersosialisasi, bertanggung jawab secara sosial, mandiri dan kooperatif dengan orang dewasa dan teman sebaya (Joseph, M.V. \& John, J., 2008). Anak dengan pengasuhan authoritative menunjukan perkembangan sosial, persepsi diri, dan kesehatan mental yang lebih baik. Pengasuhan authoritative memberikan manfaat yang lebih baik bagi masa perkembangan dibandingkan dengan pengasuhan autoritarian, permissive, dan uninvolved (Önder, A. \& Gülay, H., 2009; Rothrauff, T.C., Cooney, T.M. \& Jeong, S.A., 2009; Huver, 2010).

\section{Uninvolved/Neglegted/Rejected}

Masa perkembangan terburuk dikaitkan dengan pengasuhan uninvolved. Anak dari pengasuhan ini cenderung memiliki masalah perilaku seperti agresif, sering marah, cenderung menenentang dan menjadi anti sosial ketika remaja (Joseph, M.V. \& John, J., 2008). Pengasuhan ini menempati peringkat terendah dari semua bentuk pengasuhan. Anak cenderung kurang bisa mengendalikan diri, memiliki harga diri yang rendah, dan kurang cakap dibandingkan rekan-rekannya (Merlin, C. et al., 2013).

\section{Ibu usia remaja}

Ada beberapa definisi dari remaja, antara lain menurut World Health organization tahun 1998 mendefinisikan remaja sebagai orang muda berusia 10-19 tahun, sedang mengalami berbagai fase perubahan biologis dan tahap perkembangan psikologis yang pesat, merupakan usia yang penting bagi munculnya kemampuan mengatasi berbagai macam risiko seperti gangguan kesehatan mental, penyalahgunaan narkoba dan perilaku seksual berisiko. Remaja menghadapi masa transisi antara masa kanak-kanak dan dewasa, serta mulai mengembangkan kehidupan bermasyarakat di luar lingkungan rumahnya (DeStone, S. et al., 2016). Definisi orangtua yaitu orang yang merupakan pengasuh utama anak, tidak terbatas pada orangtua biologis atau orangtua menurut hukum, namun bisa juga orang yang memenuhi kebutuhan anak, oleh karena ada sebagaian anak yang dibesarkan oleh orang lain selain orangtua mereka (WHO, 2004).

Adapun penyebab kehamilan usia remaja antara lain adalah :

1. Kehamilan yang tidak direncanakan

Dalam hal ini, usia dari pasangan remaja yang lebih tua merupakan faktor risiko pemicu perilaku seksual yang akan menghadapkan mereka pada risiko kehamilan dan masalah kesehatan lainnya (Pinzon, Jorge; Jones, V., 2012). Selain itu pelecehan seksual merupakan penyebab kehamilan pada remaja, pemerkosaan merupakan bentuk sebuah pelecehan seksual yang mengakibatkan 
kehamilan pada remaja (Sibanda, T. \& Mudhovozi, P., 2012). Banyak remaja perempuan adalah korban pemerkosaan, sebagian melarikan diri dari rumah dan diasuh oleh mucikari dan penggunaan obat-obatan, yang selanjutnya remaja sendiri menjadi pengguna obat-obatan dan berisiko menderita AIDS (Kaplan \& Sadock's, 2007). Sangatlah penting untuk memastikan bahwa kehamilan pada remaja tersebut bukan korban kekerasan seksual. Sehingga perlu mengeksplorasi hal tersebut, dokter hendaknya terbiasa dengan hal-hal yang bernuansa hukum terutama pada kasus kehamilan remaja muda, dan bila perlu menghubungkan dengan sumber dukungan yang tepat sebagai layanan tambahan (Pinzon, Jorge; Jones, V., 2012). 2. Modernisasi media dan teknologi

Menonton televisi dan bentuk kemajuan media dan teknologi turut membentuk perilaku seksual remaja. Remaja sering mencari informasi seksual dari televisi daripada orangtua atau orang dewasa lainnya karena program televisi tersebut lebih menarik. Disatu sisi orangtua dan sekolah enggan membahas topik seksual, sehingga remaja melihat media untuk menemukan dunia dalam bahasa dan sudut pandang mereka sendiri. Umumnya remaja menerima apa yang mereka lihat dalam media sebagai sesuatu yang nyata karena tidak ada yang memberitahukan kepada mereka bahwa tidak demikian kenyataannya. Banyak produk program televisi dengan muatan seksual mulai dari ekspresi verbal, sentuhan erotis untuk berhubungan seksual, masturbasi, homoseksual dan incest. Muatan seksual dalam acara hiburan televisi memicu aktivitas seksual pada usia yang sangat muda (Yaah Baya, S. \& Mberia Sammy, 2014 ).

3. Budaya

Dalam beberapa kelompok masyarakat didapati budaya dimana pernikahan dini dan aturan tradisional merupakan faktor penting yang mempengaruhi kehamilan remaja. Sebagai contoh di beberapa wilayah Afrika dan Sahara, kehamilan pada usia remaja sering dianggap sebagai suatu anugrah karena merupakan bukti kesuburan bagi perempuan usia muda. Banyak kehamilan dari pernikahan dini ini tidak diinginkan oleh karena pasangan ini hanya ingin membuktikan kesuburannya pada keluarga (Sibanda, T. \& Mudhovozi, P., 2012). Di Indonesia budaya suku Madura menikahkan anaknya pada usia muda disebabkan kekuatiran orangtua jika anak perempuannya disebut perawan tua juga karena alasan berkurangnya kewajiban pemenuhan kebutuhan terhadap anak perempuannya yang sudah menikah (Oktaviana, R. et al., 2014). 4. Sosial ekonomi

Salah satu alasan kehamilan pada usia remaja karena status sosial ekonomi yang rendah. Sebagian besar remaja perempuan sengaja merencanakan kehamilan dengan alasan untuk mendapatkan keuntungan materi atau keuangan, membayar kesejahteraannya, serta akses memperoleh subsidi dan kebutuhan rumahtangga dari pemerintah (Aderibigbe, S.A. et al., 2011; Sibanda, T. \& Mudhovozi, P., 2012). 


\section{Permasalahan yang dihadapi ibu usia remaja}

Berkaitan dengan keterbatasan pengetahuan remaja tentang bagaimana menghadapi kehamilannya. Mereka tidak ingin memberitahukan orangtua dan akhirnya mencoba menyembunyikan kehamilan tersebut selama mereka bisa. Hal ini berefek buruk bagi kehamilannya, mereka tidak menyadari pentingnya pemberian nutrisi yang baik, terjadi anemia, serta hipertensi kehamilan yang merupakan komplikasi terbesar kehamilan remaja. Disamping itu remaja juga tidak teratur dalam perawatan prenatal karena masih belum matang dan kurang bertanggungjawab. Perkembangan tulang panggul remaja juga belum lengkap sehingga dapat menimbulkan komplikasi obstetrik dan prematuritas. Semakin muda usia ibu remaja semakin tinggi risiko kehamilan dan perawatan anaknya (WHO, 2004; Aderibigbe, S.A. et al., 2011; Pinzon, Jorge; Jones, V., 2012; Goossens, G., Kadji, C. \& Delvenne, V., 2015).

Menyangkut trauma emosional terkait dengan kehamilan yang tidak diinginkan pada usia remaja frekuensinya adalah tinggi hal ini memerlukan penanganan medis dan merupakan masalah psikososial. Masalah psikososial lainnya karena masyarakat biasanya langsung memberi penilaian buruk terhadap kehamilan remaja tanpa melihat latar belakang kehamilan tersebut.Selain itu kehamilan remaja juga akan mendatangkan beban ekonomi karena memerlukan perawatan bayi sehubungan ibu yang masih berusia sangat muda dan belum bekerja. Penyesuaian menjadi orangtua merupakan proses yang sulit bagi remaja (Klein, H.A. \& Cordell, A.S., 1987; Ziirich, U., 2000; Kaplan \& Sadock's, 2007; Aderibigbe, S.A. et al., 2011; Pinzon, Jorge; Jones, V., 2012; Sibanda, T. \& Mudhovozi, P., 2012).

\section{Pengasuhan anak oleh ibu usia remaja}

Kondisi ibu usia remaja masih belum mencapai kedewasaan dengan tuntas sehingga belum bisa bersikap mandiri, mengelola tanggungjawab yang lebih besar, berperan aktif dalam perkembangan diri sendiri, mengidentifikasikan kekuatan dan kelemahan diri sendiri, menemukan arti dan tujuan hidup dalam peran yang diperolehnya, serta menilai dan membuat perubahan hidup untuk mengatasi perubahan yang terjadi. Penyesuaian menjadi orangtua berkaitan dengan persiapan dan pengetahuan tentang perilaku perawatan anaknya. Permulaan menjadi ibu pada usia remaja banyak berkaitan dengan kesehatan mental yang buruk, misalnya gangguan mood. Disamping itu ibu usia remaja berkaitan juga dengan masih rendahnya pendidikan,tinggal dirumah menjalankan perannya sebagai orangtua, dan akan mengakibatkan kesulitan ekonomi dikemudian hari (Klein, H.A. \& Cordell, A.S., 1987; Ziirich, U., 2000; Zarrett, N., 2006; Kaplan \& Sadock’s, 2007).

Faktor lingkungan berupa dukungan sosial keluarga merupakan hal penting yang dapat mempengaruhi ibu usia remaja beradaptasi terhadap tuntutan peran sebagai orangtua. Dukungan ini penting terkait dengan masalah bagaimana sikap ibu dalam mengahadapi temperamen dari bayinya. Hal ini merupakan tanggungjawab seorang ibu untuk menanggapi dan menangkap perhatian serta kebutuhan bayi. Dukungan keluarga juga akan membantu kemampuan pengasuhan ibu. Remaja terpengaruh juga pada masalah hubungan dengan teman sebayanya. Remaja akibat kehamilannya 
terpaksa harus keluar dari sekolah dan dalam pergaulan sering dihindari oleh teman sebayanya. Sementara itu teman sebayanya masih tetap bersekolah dan bisa melakukan banyak aktivitas membuat remaja dengan kehamilan tidak terhubung dengan teman sebayanya, merasa sendiri, kesepian dan menjadi depresi. Remaja yang mengalami depresi dapat mengakibatkan kurang efektif menjalankan pengasuhan anaknya, menjadi tidak peduli terhadap anaknya, bisa juga melakukan kekerasan terhadap anaknya (Ann, B. \& Kennedy, H., 1991; Hess, C.R., Papas, M.A. \& Black, M.M., 2002; Watson, J., 2005; Goossens, G., Kadji, C. \& Delvenne, V., 2015; Ugoji, F.N., 2015).

Ibu usia remaja yang mempunyai harapan tidak sesuai terhadap kenyataan anaknya cenderung menggunakan strategi pendisiplinan yang keras dan penolakan. Pengasuhan ini termasuk jenis pengasuhan otoriter dan neglected. Selain itu pada ibu usia remaja dengan ketidakmampuannya dan kegagalan perannya sebagai orangtua cenderung menarik diri secara fisik dan emosional terhadap bayinya. Kemiskinan sering berkaitan dengan dukungan sosial yang rendah yang kemudian menyebabkan terjadinya jenis pola asuh neglected. Hal ini sering dialami sejumlah besar anak-anak yang diasuh oleh ibu usia remaja antara lain berupa pengabaian baik di bidang fisik, emosional, pengawasan, kondisi medis, pendidikan, yang semua itu merupakan kebutuhan perkembangan dasar dan perawatan yang memadai bagi anak. Pengasuhan oleh ibu usia remaja menjadi lebih buruk dengan adanya penggunaan zat, masalah kesehatan mental, kekerasan dalam rumah tangga yang dialami ibu usia remaja. Anak-anak ini bisa berkembang kearah gangguan perilaku dikemudian hari dan menempatkannya pada resiko tinggi untuk terjadinya child abuse (Watson, J., 2005; Pinzon, Jorge; Jones, V., 2012; Goossens, G., Kadji, C. \& Delvenne, V., 2015).

\section{Upaya membantu ibu usia remaja}

Ada kebutuhan mendesak dalam mendukung remaja untuk memahami dan memfasilitasi penyesuaian perannya sebagai ibu muda. Hal ini dilakukan dengan memberikan pengetahuan dan pengajaran terkait penyesuaian menjadi orangtua. Ibu dengan tingkat persiapan yang rendah, merasa lebih tidak puas dengan perannya, cenderung menggunakan hukuman fisik, jarang memegang bayinya, jarang tersenyum dan mencium bayinya ketika berinteraksi untuk memberikan stimulasi sosial (Klein, H.A. \& Cordell, A.S., 1987; Pinzon, Jorge; Jones, V., 2012).

Beberapa upaya yang bisa dilakukan untuk membantu ibu usia remaja adalah :

1. Meningkatkan pola perawatan bayi

Dalam hal ini upaya yang dilakukan dengan mengajarkan ibu tentang gaya interaksi untuk meningkatkan respon terhadap bayinya dengan memberikan rangsangan visual dan auditori, memberikan kontak fisik yang cukup untuk perkembangan sosial, serta dengan menyiapkan pembelajaran keterlibatan ibu dalam kelas pendidikan melahirkan, kelas perawatan bayi, dan memberikan bacaan yang sesuai (Klein, H.A. \& Cordell, A.S., 1987).

2. Mengupayakan program pencegahan kehamilan kedua

Diperlukan juga program pencegahan kehamilan kedua pada remaja supaya lebih fokus pada tujuan untuk mendukung pendidikan bagi remaja dan memotivasi menunda kehamilan kedua, dengan 
memberikan pengetahuan dan akses ke layanan kontrasepsi. Disarankan penggunaan kontrasepsi jangka panjang, yang secara bermakna lebih rendah angka kehamilannya dibanding kontrsepsi oral (Pinzon, Jorge; Jones, V., 2012).

3. Program membantu ibu usia remaja kembali ke sekolah

Untuk hal ini perlu program berbasis sekolah yang dapat memberikan layanan untuk kehamilan dan pengasuhan sementara mereka bersekolah. Sekolah berbasis program perawatan anak memberikan fasilitas remaja dalam sekolah, antara lain penitipan anak gratis, menyediakan dukungan dan pendidikan pengasuhan menjadi orangtua, dan dapat membantu dalam meningkatkan kesehatan dan perkembangan anaknya. Suatu program multidisiplin selain berbasis sekolah, antara lain menyediakan perawatan medis, dukungan psikologis, pendekatan ketrampilan komprehensif bagi ibu usia remaja dengan melibatkan ibu usia remaja supaya dapat bekerja, mendapat tambahan jam kerja, sehingga dapat menyimpan lebih banyak uang (Pinzon, Jorge; Jones, V., 2012).

\section{Program kemitraan}

Adalah model lain dari program membantu ibu usia remaja dengan mengikutsertakan perawatan oleh anggota keluarga, pekerja sosial, juga home visit oleh petugas medis terutama bagi remaja berisiko tinggi yaitu dengan pengalaman pertama sebagi ibu usia remaja. Dengan tujuan yaitu keberhasilan kesehatan, kesejahteraan bayi dan perkembangan anak, serta kesejahteraan ibu. Secara umum ibu usia remaja membutuhkan bimbingan dan dukungan intensif dalam jangka waktu lama. Akan tetapi hal ini juga dapat memberikan efek bertentangan sebagai hal yang tidak diinginkan oleh ibu usia remaja, atau dukungan berlebihan akan menjurus kearah timbulnya perasaan tidak berdaya dan kesedihan yang akan memperberat kondisi depresinya (Pinzon, Jorge; Jones, V., 2012; Goossens, G., Kadji, C. \& Delvenne, V., 2015).

\section{RINGKASAN}

Remaja yang berperan sebagai seorang ibu berpengaruh terhadap pengasuhan dan perkembangan anaknya. Ibu usia remaja dalam berinteraksi dengan anaknya cenderung menggunakan cara pendisiplinan keras yang berhubungan dengan kemarahan terhadap anak dan penolakan sehingga hubungan ibu dan anak menjadi bermasalah. Selain itu remaja yang berperan sebagai ibu kurang memiliki pengetahuan tentang pentingnya berinteraksi dengan bayi yang mengakibatkan pengabaian, hal ini ditambah dengan kondisi kemiskinan dan dukungan sosial yang rendah menyebabkan pola pengasuhan cenderung neglected.

Dalam situasi seperti ini diperlukan perhatian yang tidak hanya tertuju pada usaha pencegahan kehamilan pada remaja saja, namun dibutuhkan juga upaya mendukung remaja dalam pengasuhan anaknya. Dukungan terhadap pengasuhan pada ibu usia remaja merupakan hal penting yang mempengaruhi perkembangan sosial emosional anak bagi tercapainya kesejahteraan generasi berikutnya dalam masyarakat. 


\section{KEPUSTAKAAN}

Aderibigbe, S.A. et al., 2011. Teenage pregnancy and prevalence of abortion among in-school adolescents in north central, Nigeria. Asian Social Science, 7(1), pp.122-125.

Alizadeh, S. et al., 2011. Relationship between parenting style and children's behavior problems. Asian Social Science, 7(12), pp.195-200.

Ann, B. \& Kennedy, H., 1991. The impact of parents and peers on teenage sexual behavior., IOWA State University Digital Repository, 100/16.

Baumrind, D. 1991., The influence of parenting style on adolescent competence and substance use. Journal Of Early Adolescence, 11(1), 56-95.

Daniel, K., 2016. The Effect of Peer Presence on Adolescent Risk-Taking Behaviors. Georgia Southern University., April., paper 181, Available at: http://digitalcommons.georgiasouthern.edu/honors-theses/181/.

Darling, N., 1999. Parenting style and its correlates. ERIC Digest. Eric Digest, pp.1-7. Available at: http://bern.library.nenu.edu.cn/upload/soft/0-article/+025/25104.pdf.

DeStone, S. et al., 2016. Factors Associated with Good and Harsh Parenting of Pre-Adolescents and Adolescents in Southern Africa., UNICEF Office of Reseach-Innocenti working paper., (November)., WP 20., Available at: https://www.unicef-irc.org/publications/870/.

Goossens, G., Kadji, C. \& Delvenne, V., 2015. Teenage pregnancy: a psychopathological risk for mothers and babies? Psychiatria Danubina, 27, pp.S499-S503.

Hess, C.R., Papas, M.A. \& Black, M.M., 2002. Resilience among African American adolescent mothers: Predictors of positive parenting in early infancy. Journal of Pediatric Psychology, 27(7), pp.619-629.

Huver, R.M.E. et al., 2010. Personality and parenting style in parents of adolescents. Journal of Adolescence, 33(3), pp.395-402. Available at: http://dx.doi.org/10.1016/j.adolescence.2009.07.012.

Joseph, M.V. \& John, J., 2008. Impact of Parenting Styles on Child Development. Global Academic Society Journal: Social Science Insight, 1(5), pp.16-25.

Kaplan \& Sadock's, 2007. Synopsis of Psychiatry Behavioral Sciences/ Clinical Psychiatry. 10th Ed. Philadelphia, USA : Lippincott Williams \& Wilkins, a Wolters Kluwer Business.

Klein, H.A. \& Cordell, A.S., 1987. The adolescent as mother: Early risk identification. Journal of Youth and Adolescence, 16(1), pp.47-58.

Kordi, A., 2010. Parenting Attitude and Style and Its Effect on Children's School Achievements. Journal Of Psychological Studies, 2(2), pp.217-222.

Li, Z. et al., 2011. Australia's mothers and babies 2011., The Australian Institute of Health and Welfare, 59(Number28).

Merlin, C. et al., 2013. How Parenting Style Influences Children : A Review of Controlling, Guiding, and Permitting Parenting Styles on Children's Behavior, Risk- Taking, Mental Health , and Academic Achievement., The William\& Mary Educational Review., Vol.2(1).art.14., pp32-43.

Oktaviana, R. et al., 2014. Hubungan Riwayat Usia Pernikahan dengan Sikap Ibu dalam Perawatan Bayi Baru Lahir di Wilayah Keja Puskesmas Silo Kabupaten Jember ( The Correlation Between 
History of Marriage Age to Mother' s Attitude in Newborn Care in Work Area Public Health Center of Silo Jember Regency., Artikel Ilmiah Hasil Penelitian Mahasiswa, 041.

Önder, A. \& Gülay, H., 2009. Reliability and validity of parenting styles \& dimensions questionnaire. Procedia - Social and Behavioral Sciences, 1(1), pp.508-514.

Pinzon, Jorge; Jones, V., 2012. Care of Adolescent Parents and Their Children. American Academy of Pediatrics,130(Number6),pp.429-434. Available at:

http://pediatrics.aappublications.org/content/107/2/429.full/nhttp://pediatrics.aappublications.org/ cgi/doi/10.1542/peds.107.2.429.

Rothrauff, T.C., Cooney, T.M. \& Jeong, S.A., 2009. Remembered parenting styles and adjustment in middle and late adulthood. Journals of Gerontology - Series B Psychological Sciences and Social Sciences, 64(1), pp.137-146.

Sibanda, T. \& Mudhovozi, P., 2012. Becoming a single teenage mother: a vicious cycle. Journal of social sciences, 32(3), pp.321-334. Available at:

http://search.proquest.com/docview/1353279877?accountid=13828\nhttp://find.shef.ac.uk/openu rl/44SFD/44SFD_services_page?url_ver=Z39.88-

2004\&rft_val_fmt=info:ofi/fmt:kev:mtx:journal\&genre=article\&sid=ProQ:ProQ:ibssshell\&atitle $=$ Becoming $+\mathrm{a}+$ single+teenage + mot.

Terry, D.J., 2004. Investigating the Relationship between Parenting Styles and Delinquent Behavior Investigating the Relationship between Parenting Styles. Parenting, 15(1), pp.1484-1487. Available at: http://linkinghub.elsevier.com/retrieve/pii/S1877042811004940.

Ugoji, F.N., 2015. Parenting Styles , Peer Group Influence as Correlate of Sexual Behaviour among Undergraduate Adolescents., International Journal of Humanities Social Sciences and Education., August Vol.2(8), pp.103-110.

Unicef, 2011. Adolescence An Age of Opportunity, United Nations Children's Fund (UNICEF), February, E.11.XX.1. Available at: www.unicef.org.

Watson, J., 2005. Child neglect: Center for Parenting \& Research., May., pp.1-64.

WHO, 2004. Adolescent Pregnancy: Issues in Adolescent Health and Development., World Health Organization., WS 460.

Yaah Baya, S. \& Mberia Sammy., 2014. The Impact of Television Viewing in Influencing Adolescents Sexual Behaviour. International Journal of Scientific and Research Publications, 4(1), pp.2250-3153. Available at: www.ijsrp.org.

Zarrett, N\& Eccles, J.,2006., The Passage to Adulthood: Challenges of Late Adolescence., New Directions for Youth Development.,No 111.

Ziirich, U., 2000., Stages of Adolescent Development., Upstate Center of Excellence, May 2004,600, pp.23-36. 